\section{Myoedema and Vitamins}

SIR,-In 1953 Chhuttani and Taylor ${ }^{2}$ stated that myoedema was related to thiamine deficiency, and Berry has recently disputed this. $^{3}$ At the same meeting at which Berry put forward his views I am on record as having stated that myoedema was unrelated to vitamin status. ${ }^{*}$ Subsequent careful analysis has shown that this initial statement was not entirely correct. In our study of 80 elderly hospitalized patients, who had been divided into two groups, one of which was given a multivitamin supplement and the other given dummy tablets, we are now able to show that the presence or absence of myoedema, though unrelated to vitamin-C supplementation, was in fact related to supplementation with B-group vitamins.

After 12 months of daily supplementation with ascorbic acid $200 \mathrm{mg}$., thiamine $15 \mathrm{mg}$., riboflavine $15 \mathrm{mg}$, nicotinamide $30 \mathrm{mg}$, and pyridoxine $10 \mathrm{mg}$., or matching dummy tablets, the figures have been re-examined as shown in the Tables. The first two Tables relate the presence or absence of myoedema to the biochemical state of the individual in relation to ascorbic acid and thiamine at the end of the trial, while the third Table relates the presence or absence of myoedema to whether the patien was on active or dummy tablets. Only 54 out of 80 cases were available for assessment at the end of the trial because of deaths, and in four cases it was impossible to elicit myoedema because of the physical condition of the patient

Myoedema was taken as being absent if the biceps could be stimulated by puncture and produced no ridge, and as present if a

TABLE I.-Myoedema Related to Leucocyte Ascorbic Acid
Supplementation

\begin{tabular}{|c|c|c|c|}
\hline & $\begin{array}{c}\text { "Below } \\
\text { Average" } \\
\text { Vitamin } \\
\text { C }\end{array}$ & $\begin{array}{c}\text { Not } \\
\text { Deficient } \\
\text { in } \\
\text { Vitamin C }\end{array}$ & Total \\
\hline $\begin{array}{l}\text { Myoedema present } \\
\text { Myoedema absent }\end{array}$ & $\begin{array}{r}10 \\
1\end{array}$ & $\begin{array}{l}31 \\
12\end{array}$ & $\begin{array}{l}41 \\
13\end{array}$ \\
\hline Totals & 11 & 43 & 54 \\
\hline
\end{tabular}

TABLE II.-Myoedema Related to T.P.P. Effect After 12 Months' Supplementation

\begin{tabular}{r|c|c|c}
\hline & $\begin{array}{c}\text { "Below } \\
\text { Average } \\
\text { in B }\end{array}$ & $\begin{array}{c}\text { Not } \\
\text { Deficient } \\
\text { in } B_{1}\end{array}$ & Total \\
\hline $\begin{array}{c}\text { Myoedema present } \\
\text { Myoedema absent }\end{array}$ & 21 & 20 & 41 \\
\hline Totals & 22 & 32 & 54 \\
\hline \multicolumn{2}{l}{$\chi^{2}=6.047 . \quad P=0.01}$.
\end{tabular}

TABLE III.-Myoedema Related to 12 Months' Taking of Multivitamin Supplements or Dummy Tablets

\begin{tabular}{c|c|c|c}
\hline & $\begin{array}{c}\text { On } \\
\text { Active } \\
\text { Tablets }\end{array}$ & $\begin{array}{c}\text { On } \\
\text { Dummy } \\
\text { Tablets }\end{array}$ & Total \\
\hline $\begin{array}{c}\text { Myoedema present } \\
\text { Myoedema absent }\end{array}$ & $\begin{array}{c}17 \\
12\end{array}$ & $\begin{array}{r}24 \\
1\end{array}$ & $\begin{array}{c}41 \\
13\end{array}$ \\
\hline Totals $\quad \cdot$ & 29 & 25 & 54 \\
\hline \multicolumn{2}{c}{$\chi^{2}=8.319 . \quad P=0.001}$.
\end{tabular}

ridge was produced. Table I shows that there was no relationship between myoedema and the leucocyte vitamin-C level. Table II shows a strong statistical relationship between the presence or absence of myoedema and the thiamine status, as measured by the thiamine pyrophosphate (T.P.P.) effect, while Table III shows more a significant relationship between the presence or absence of myoedema and the taking of active or dummy tablets for a year.-I am, etc.,

\section{Department of Pathology, \\ Farnborough Hospital
Orpington, Kent.}

L. L. Griffiths.

REFERENCES

${ }^{1}$ Chhuttani, P. N., and Taylor, G. F., Indian

Taylor, G. F., and Chhuttani, P. N., British

3 Berry, W. T. C., in Vitamins in the Elderly, edited by A. N. Exton-Smith and D. L Scots right.

Griffiths, L. L., in Vitamins in the Elderly, ediced by A. N. Exton-Smith and D. L. Scott, 1968, p. 38. Bristol, John Wright.

\section{Radiology's New Chance}

SIR,-Mr. C. K. Warrick (28 June, p. 821) deplored the salaries currently paid to senior radiographers and sought to strengthen his case by comparing the salaries of a superintendent radiographer grade III and a principal grade II of a school of physiotherapy. The case for higher salaries for radiographers -and for physiotherapists and others in the National Health Service-commands massive support in every informed quarter other than the one where it matters most, but it will not be strengthened by comparing like with unlike. The facts are:

(1) Superintendent radiographer III (the top clinical grade with responsibility for 20 or more assistants), $£ 1,286-£ 1,668$.

(2) Superintendent physiotherapist V (the top clinical grade with responsibility for 20 or more assistants), $£ 1,286-£ 1,668$.

(3) Principal " A" of radiography school (the top teaching grade with responsibility for an average annual student intake of ten or more), $£ 1,282-£ 1,663$.

(4) Principal II of physiotherapy school (the top teaching grade with responsibility for an annual student intake of 25 or more), $£ 1,570-£ 2,050$. - I am, etc.,

JACK Rose,
Chartered Society of Physiotherapy.
London W.C.1.

SIR,-I have been slow in appreciating the advantages of an increased proportion of male radiographers as the appropriate answer to two of our more recent problems.

Firstly, good senior radiographers are in short supply owing to the earlier age of marriage of our predominantly female staff. This category are keen members of the establishment responsible for the efficient organization of turnover in the $x$-ray rooms, and also for imparting the practical advice which is so valuable in improving the quality of output of the junior radiographers. Secondly, the male radiographer is at a distinct advantage in assisting the increasing number of older disabled patients who are now being referred for examination.

I have been loath to accept prospective male students and find I am dissuading them from entering the profession. Before I can actively entice the quality which we need I must see a career structure which will ensure that the senior male radiographer can comfortably support a family comparable with his open market value. Promotion to senior grade three years after qualification is rewarded by an addition of $£ 16$ per annum to the basic rate of pay ; after a further four years the differential enjoyed by seniors over the basic scale has become $£ 14$ per annum.

Such disincentives lead to impoverishment of intake, impaired suitability of our juniors for promotion, and particularly impoverishment of the key senior grade. I venture to suggest that these are the hallmarks of a great monopoly.-I am, etc.,

\section{General Hospital,
Northampton.}

\section{G. HOLlingswORTH.}

\section{Arsenic in Water}

SIR,-Your leading article on arsenic in water (12 July, p. 70) contains the sentence, "Evidence of some poisoning is rare, even with 4-5 mg. per litre of urine."

Although rareness is a matter of opinion, I immediately put my hand on analytical details of 13 cases in which 7 had levels at or below $5 \mathrm{mg} . /$ litre.-I am, etc.,

\section{A. S. CURry,} Director,
Home Office Central Research
Establishment.

Aldermaston, Berks.

SIR,-In view of the leading article (12 July, p. 70) concerning arsenic in water, you may be interested to know that in 1941, when we were both getting periodic cases of arsenical poisoning from miners who worked in Castle-an-dinas wolfram [tungsten] mine in our area, one night our over-enthusiastic fire brigade accidentally nearly pumped our local reservoir dry. Late that night, a young maid one of us had made us a cup of tea from very muddy water (luckily we discovered this before drinking much).

Within an hour we had typical symptoms of arsenical poisoning: nausea, pain, vomiting, faintness, acute cramps in the legs, and later diarrhoea. My father, who was present, and who, though not a doctor, had had a shortened medical course at the Middlesex Hospital before going pioneering abroad, immediately diagnosed acute arsenical poisoning, as did also the other partner. With treatment we speedily recovered and no actual tests were carried out. By morning the water supply had cleared of its mud and we had no other cases; for one thing by the time we used the water most of the population were in bed, and would not have drunk muddy water anyway, any more than we should, had we ourselves seen it before the tea was made. We have however always thought our diagnosis was correct; one of us can vouch personally for the fact that he has never suffered from anything else like it before or since.We are, etc.,

T. M. Crabtree.

St. Dennis,

C. M. WILSON. 